\title{
Sodium and potassium alginates extracted from Macrocystis pyrifera algae for use in dental impression materials
}

\author{
Alginatos de sodio y potasio extraídos del alga Macrocystis pyrifera \\ para usos en materiales para impresión dental
}

\author{
Raúl Reyes-Tisnado ${ }^{{ }^{*}}$ \\ Gustavo Hernández-Carmona ${ }^{2, a}$ \\ Francisco López-Gutiérrez ${ }^{2}$ \\ Eduardo Jaime Vernon-Carter ${ }^{\mathrm{a}}$ \\ Pastor Castro-Moroyoqui ${ }^{1}$ \\ ${ }^{1}$ Centro Regional de Investigación Pesquera \\ $\mathrm{Km} 1$ Carretera a Pichilingue \\ La Paz, Baja California Sur, México \\ *E-mail: rulreyes@prodigy.net.mx \\ ${ }^{2}$ Centro Interdisciplinario de Ciencias Marinas \\ Apartado postal 592 \\ La Paz, CP 23000, Baja California Sur, México \\ ${ }^{3}$ Universidad Autónoma Metropolitana Iztapalapa \\ DCBI (IPH) \\ México, CP 09340, DF
}

Recibido en octubre de 2002; aceptado en octubre de 2003

\begin{abstract}
Sodium and potassium alginates were extracted at the pilot plant scale from the giant kelp, Macrocystis pyrifera, from Bahía Tortugas, Baja California Sur, Mexico. Alginates were coded as S1, S2 and S3 for sodium alginate, and as P1, P2 and P3 for potassium alginate. The average viscosities of the sodium and potassium alginates in aqueous $1 \%$ solution were 58,145 and $506 \mathrm{mPa} \mathrm{s}$, and 48, 155 and $200 \mathrm{mPa}$ s, respectively. Results showed that dental impresion material prepared with sodium alginate with extra low viscosities $(\mathrm{S} 1=58 \mathrm{mPa} \mathrm{s})$ and low viscosities $(\mathrm{S} 2=145 \mathrm{~m} \mathrm{~Pa} \mathrm{~s})$ did not form gels, the material prepared with medium viscosity ( $\mathrm{S} 3=506 \mathrm{mPa}$ ) produced a gel type II (regular set) in $70 \%$ of the 10 formulations experimented, and the material prepared with potassium alginate with extra low viscosity $(\mathrm{P} 1=48 \mathrm{mPa}$ s) produced a gel type II in $90 \%$ of the formulations. Using potassium alginate with low viscosity $(\mathrm{P} 2=155 \mathrm{mPa} \mathrm{s}), 90 \%$ of the formulations were type I (fast set), and using potassium alginate with medium viscosity $(\mathrm{P} 3=200 \mathrm{mPa} \mathrm{s}), 80 \%$ of the formulations were type I. The highest compressive strength was obtained using sodium alginate of $506 \mathrm{mPa} \mathrm{s}$ and the three potassium alginates experimented at $25 \%$ concentration, with values of 2474, 1209, 2101 and $2124 \mathrm{~g} \mathrm{~cm}^{-2}$ for S3, P1, P2 and P3 alginates, respectively. The elasticity order of formulation with $25 \%$ alginates compared with a commercial product (Jeltrate ${ }^{\circledR}$ ) was as follows: Jeltrate ${ }^{\circledR}>\mathrm{P} 2>\mathrm{S} 3>\mathrm{P} 3>\mathrm{P} 1$. It was concluded that S3, P1, P2 and P3 alginates have good potential for use in the production of dental impression materials.
\end{abstract}

Key words: alginates, Macrocystis pyrifera, algae, dental impression material.

\section{Resumen}

Se extrajeron alginatos de sodio y de potasio a escala piloto del alga Macrocystis pyrifera proveniente de Bahía Tortugas, Baja California Sur, México. Los alginatos fueron codificados como alginatos de sodio (S1, S2 y S3) y alginatos de potasio (P1, P2 y P3). Las viscosidades medias de los alginatos de sodio y de potasio en solución acuosa al 1\% fueron de 58,145 y $506 \mathrm{mPa} \mathrm{s}$, y 48, 155 y $200 \mathrm{mPa}$ s, respectivamente. Los resultados mostraron que el material para impresiones dentales preparado con los alginatos de sodio con viscosidades extra bajas $(\mathrm{S} 1=58 \mathrm{mPa} s)$ y viscosidades bajas $(\mathrm{S} 2=145 \mathrm{mPa})$ no formó geles, el material preparado con viscosidades medias $(\mathrm{S} 3=506 \mathrm{mPa} \mathrm{s}$ ) produjo geles tipo II (fraguado normal) en $70 \%$ de las 10 formulaciones

\footnotetext{
${ }^{a}$ Becario por exclusividad de la COFAA-IPN y EDI-IPN.
} 
experimentadas, y el material preparado con alginatos de potasio con viscosidad extra baja (P1 $=48 \mathrm{mPa}$ s) produjo geles tipo II en $90 \%$ de las formulaciones. Usando alginatos de potasio con viscosidad baja ( $22=155 \mathrm{mPa}$ ), $90 \%$ de las formulaciones fueron de tipo I (fraguado rápido), y usando alginato de potasio con viscosidad media ( $\mathrm{P} 3=200 \mathrm{mPa}$ s), $80 \%$ de las formulaciones fueron de tipo I. La más alta resistencia a la compresión fue obtenida usando alginato de sodio de $506 \mathrm{mPa} \mathrm{s}$ y los tres alginatos de potasio experimentados a concentración de 25\%, con valores de 2474, 1209, $2101 \mathrm{y} 2124 \mathrm{~g} \mathrm{~cm}^{-2}$ para los alginatos S3, P1, P2 y P3, respectivamente. El orden de elasticidad de las formulaciones con $25 \%$ de alginatos comparados a un producto comercial (Jeltrate ${ }^{\circledR}$ ) fue el siguiente: Jeltrate ${ }^{\circledR}>\mathrm{P} 2>\mathrm{S} 3>\mathrm{P} 3>\mathrm{P} 1$. Se concluye que los alginatos S3, P1, P2 y P3 tienen un buen potencial para usarse en la producción de material de impresión dental.

Palabras clave: alginatos, Macrocystis pyrifera, algas, impresiones dentales.

\section{Introduction}

Alginate is the salt of alginic acid, a polysaccharide constituted by the unbranched binary copolymer of $\beta$-D-manuronic $(\mathrm{M})$ and $\alpha$-L-guluronic $(\mathrm{G})$ acids, structured in sequences of MM, MG blocks joined by $\beta(1-4)$ bonds, and GG, GM blocks joined by $\alpha(1-4)$ bonds. Alginates are structural polysaccharides of the amorphous matrix of the cellular wall in brown seaweeds such as Macrocystis pyrifera (L.) C. Agardh. Their function is to give strength and flexibility to the algal tissue (Skjäk-Braek and Martinsen, 1991; Smidsrod and Draget, 1996).

Sodium and potassium alginates are hydrocolloid materials commonly used in dental impressions. Dentists use them in powder form together with other components to prepare the material with the appropriate viscosity, which is transported to the patient's mouth by means of an impression tray. The gelling process takes place in the mouth and, after a few minutes, the impression is removed. There are several methods of producing the gel, but one of the easiest is to use a soluble alginate, which reacts with calcium sulfate to produce an insoluble calcium alginate. In fact, this reaction should occur in the mouth, and it is therefore necessary to slow down the reaction with trisodium phosphate, while the dental material is mixing with water. The paste is placed on the impression tray and then in the mouth. At present, alginates are widely used in dental impression materials because they are easy to handle, comfortable for patients and do not require sophisticated equipment. They are also used in dental prostheses, as models for studying jagged and toothless mouth impressions (Skinner and Phillips, 1982; Osborne et al., 1987).

The use of alginates in dental impression materials is based on the aqueous reaction between a sparingly soluble calcium salt (usually calcium sulfate dihydrate) and an alginate. A common formula for a dental impression material, based on the above description, is as follows: $12 \%$ of sodium or potassium alginate, $12 \%$ of calcium sulfate, $2 \%$ of trisodium phosphate, and $74 \%$ of diatomaceous earth. The exact proportions of the formula vary accordingly to the type of alginate used. The chemical composition of the alginates can greatly affect the gel strength. Alginates with high content of guluronic acids characteristically yield materials with high gel strength. The quantity of retarder should be adjusted carefully in order to provide the appropriate gelling time. Trisodium phosphate is a retardant, while calcium sulfate is the reactant used to promote

\section{Introducción}

El alginato es la sal del ácido algínico, un polisacárido constituido por un copolímero binario no ramificado de los ácidos $\beta$-D-manurónico (M) y $\alpha$-L-gulurónico (G), estructurado en secuencias de bloques MM, MG unidos por enlaces $\beta(1-4)$, y bloques GG, GM unidos por enlaces $\alpha(1-4)$. Los alginatos son polisacáridos estructurales de la matriz amorfa de la pared celular de las algas cafés tales como Macrocystis pyrifera (L.) C. Agardh. Su función es dar rigidez y flexibilidad al tejido algal (Skjäk-Braek y Martinsen, 1991; Smidsrod y Draget, 1996).

Los alginatos de sodio y potasio son materiales hidrocoloidales comúnmente usados en impresiones dentales. Los dentistas los utilizan pulverizados, agregándoles otros componentes para preparar el material con la viscosidad apropiada, y se colocan en la boca del paciente por medio de un portaimpresiones. El proceso de gelificado se lleva a cabo en la boca y, después de pocos minutos, la impresión se retira. Hay varios métodos para producir el gel, pero uno de los más sencillos es usar un alginato soluble, el cual reacciona con sulfato de calcio para producir un alginato de calcio insoluble. En realidad, dicha reacción debe ocurrir en la boca, y por ese motivo, se hace necesario retardarla con fosfato trisódico mientras que el material dental se mezcla con agua. La pasta se coloca en el porta-impresiones, y entonces se lleva a la boca. Actualmente, los alginatos son ampliamente usados en materiales de impresión dental, ya que son de fácil manejo, confortables para el paciente y su uso no requiere de equipo sofisticado. También son usados en prótesis dentales, como modelos de estudio de impresiones de boca dentadas y desdentadas (Skinner y Phillips, 1982; Osborne et al., 1987).

El uso de los alginatos en materiales de impresión dental está basado en la reacción acuosa entre una sal de calcio poco soluble (usualmente sulfato de calcio dihidratado) y un alginato. Una fórmula común para material de impresión dental, basada en lo antes descrito, es la siguiente: $12 \%$ de alginato de sodio o potasio, $12 \%$ de sulfato de calcio, $2 \%$ de fosfato trisódico y $74 \%$ de tierra de diatomeas. La proporción exacta de la fórmula puede variar de acuerdo con el tipo de alginato utilizado. La composición química del alginato puede afectar grandemente la fuerza de gel. Alginatos con altos contenidos de ácidos gulurónicos se caracterizan por producir materiales 
gel formation. In this way, if appropriate quantities of potassium alginate, calcium sulfate and trisodium phosphate are mixed with water, the following reaction takes place: $2 \mathrm{Na}_{3} \mathrm{PO}_{4}+3 \mathrm{CaSO}_{4} \rightarrow \mathrm{Ca}_{3}\left(\mathrm{PO}_{4}\right)_{2}+3 \mathrm{Na}_{2} \mathrm{SO}_{4}$. When there is no more trisodium phosphate available, the calcium ions of calcium sulfate begin to react with the potassium alginate to form a calcium alginate gel (dental impression) as follows: $\mathrm{Kn} \mathrm{Alg}+{ }_{n / 2} \mathrm{CaSO}_{4} \rightarrow{ }_{\mathrm{n} / 2} \mathrm{~K}_{2} \mathrm{SO}_{4}+\mathrm{Ca}_{\mathrm{n} / 2}$ Alg.

According to the gelling time, two types of dental impression material are specified: type I (fast set), with a gelling time of 0-120 s, and type II (regular set), with a gelling time of around $121-420 \mathrm{~s}$. Diatomaceous earth is a filling material that increases the resistance and rigidity of alginate gel when used in appropriate amounts, providing a uniform texture and lack of superficial adhesion (Skinner and Phillips, 1982; Onsoyen, 1996).

The giant kelp, Macrocystis pyrifera, is one of the brown seaweeds that are commercially exploited as a source of alginates (McHugh, 1987; Reyes-Tisnado et al., 1992). In Mexico, giant kelp distribution extends from the border with the United States of America to Punta San Hipólito, Baja California Sur. The estimated harvestable biomass ( $1 \mathrm{~m}$ below the sea surface) varies seasonally between 36,520 $t$ in winter and 99,626 $t$ in summer (Hernández-Carmona et al., 1989a, 1989b, 1991).

At the present time in Mexico, M. pyrifera is harvested and exported to the United States as raw material for alginate production; however, all alginates and dental impression materials used in the country are imported mainly from the United States, Norway, England, Germany, Italy and the Netherlands (Reyes-Tisnado et al., 2000). Efforts are being made to develop an alginate production industry in Mexico based on the rational and efficient exploitation of M. pyrifera, thus contributing to the regional development of Baja California Sur and to decrease imports of these materials.

To determine the potential use of alginates from $M$. pyrifera, it was necessary to carry out studies related to their properties and applications. The objective of this research was to produce sodium and potassium alginates from M. pyrifera at the pilot plant level, and to determine their general properties and test their use for the preparation of dental impression material. Another objective was to analyze the gelling time of the dental impression materials, the compressive strength, and the rheological characteristics (storage modulus, loss modulus and loss factors) of the dental impression materials.

\section{Material and methods}

\section{Extraction of sodium and potassium alginates at the pilot plant scale}

Ten kilograms of dried and milled alga ( $M$. pyrifera), harvested from Bahía Tortugas, Baja California Sur, Mexico, were placed in a tank to hydrate overnight with $90 \mathrm{~L}$ of $0.1 \%$ formalin solution. The residual solution was drained off and the alga was washed with $100 \mathrm{~L}$ of hydrochloric acid solution con alta fuerza de gel. La cantidad de retardador se deberá ajustar cuidadosamente para proveer un tiempo de gelificado adecuado. El fosfato trisódico es un retardador, mientras que el sulfato de calcio es el reactante usado para promover la formación del gel. De esta manera, si se mezclan cantidades adecuadas de alginato de potasio, sulfato de calcio y fosfato trisódico, con agua, se lleva a cabo la siguiente reacción: $2 \mathrm{Na}_{3} \mathrm{PO}_{4}+3 \mathrm{CaSO}_{4} \rightarrow \mathrm{Ca}_{3}\left(\mathrm{PO}_{4}\right)_{2}+3 \mathrm{Na}_{2} \mathrm{SO}_{4}$. Cuando no hay más fosfato trisódico disponible, los iones de calcio del sulfato de calcio comienzan a reaccionar con el alginato de potasio para formar un gel de alginato de calcio (impresión dental) de la siguiente manera: $\mathrm{K}_{\mathrm{n}} \mathrm{Alg}+{ }_{\mathrm{n} / 2} \mathrm{CaSO}_{4} \rightarrow{ }_{\mathrm{n} / 2} \mathrm{~K}_{2} \mathrm{SO}_{4}+\mathrm{Ca}_{\mathrm{n} / 2} \mathrm{Alg}$.

De acuerdo con el tiempo de gelificado, se han especificado dos tipos de material de impresión dental: el tipo I (fraguado rápido), con un tiempo de gelificado entre 0 y $120 \mathrm{~s}$, y el tipo II (fraguado normal), cuyo tiempo de gelificado es entre $121 \mathrm{y}$ 420 s. La tierra de diatomeas es el material de relleno que incrementa la rigidez del gel de alginato cuando es usada en cantidades adecuadas; confiere una textura uniforme y elimina la adhesión superficial al material (Skinner y Phillips, 1982; Onsoyen, 1996).

El sargazo gigante, Macrocystis pyrifera, es una de las algas marinas cafés que son explotadas comercialmente como fuente de alginatos (McHugh, 1987; Reyes-Tisnado et al., 1992). En México la distribución del sargazo gigante se extiende desde la frontera con los Estados Unidos de América hasta Punta San Hipólito, Baja California Sur. La biomasa cosechable estimada ( $1 \mathrm{~m}$ abajo de la superficie marina) varía estacionalmente desde 36,520 $\mathrm{t}$ en invierno hasta 99,626 $\mathrm{t}$ en verano (Hernández-Carmona et al., 1989a, 1989b, 1991).

Actualmente, en México, M. pyrifera es cosechada y exportada a los Estados Unidos como materia prima para la producción de alginatos; sin embargo, todos los alginatos y materiales de impresión dental utilizados en el país son importados principalmente de los Estados Unidos, Noruega, Inglaterra, Alemania, Italia y Holanda (Reyes-Tisnado et al., 2000). Existen esfuerzos para desarrollar una industria de producción de alginatos en México con el propósito de explotar racional y eficientemente el alga marina $M$. pyrifera, lo que contribuiría al desarrollo regional en Baja California Sur y a disminuir las importaciones de estos materiales.

Para determinar el uso potencial de los alginatos de M. pyrifera fue necesario realizar estudios relacionados con sus propiedades y aplicaciones. El objetivo de esta investigación fue producir alginato de sodio y de potasio del alga M. pyrifera, a nivel de planta piloto, para determinar sus propiedades generales y probar su uso para la elaboración de material de impresión dental. Otro objetivo fue analizar los tiempos de gelificado, la resistencia a la compresión y las características reológicas (módulos de almacenamiento, módulos de pérdida y factores de pérdida) de los materiales de impresión dental. 
at $\mathrm{pH} 4$ in the same tank for $15 \mathrm{~min}$, with constant agitation (Hernández-Carmona et al., 1999a). The alga was transferred to an extraction kettle containing $166 \mathrm{~L}$ of water; the $\mathrm{pH}$ was adjusted to 10 using powdered sodium carbonate and the solution was heated to $80^{\circ} \mathrm{C}$ for $2 \mathrm{~h}$, with constant stirring. The resulting paste was then diluted to $45 \mathrm{mPa}$ s and filtered in a rotary vacuum filter, using diatomaceous earth as the filter aid (Hernández-Carmona et al., 1999b). During filtration, the alginate solution was pumped into the precipitation tank, while a solution of $10 \%$ calcium chloride was added simultaneously to precipitate it as calcium alginate, using a proportion of 2.2 parts of calcium chloride to 1 part of alginate in solution. The calcium alginate fibers were bleached using $700 \mathrm{~mL}$ of $5 \%$ sodium hypochlorite solution and converted to alginic acid, with three acid washings at $\mathrm{pH} 2,1.8$ and 1.8. The alginic acid fibers obtained were pressed using a hydraulic press to remove as much water as possible (McHugh et al., 2001). To obtain the sodium or potassium alginate, alginic acid fibers were neutral-

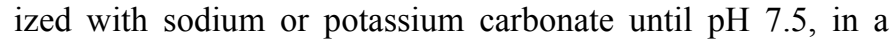
double planetary mixer during $40 \mathrm{~min}$. The sodium or potassium alginate fibers were separated and dried at $60^{\circ} \mathrm{C}$ for enough time to get a product with $12 \%$ moisture content (Hernández-Carmona et al., in press). Samples of three types of sodium and potassium alginates were extracted from plants collected on different dates in order to have alginate samples with different viscosities, and they were coded, according to the viscosity, as $\mathrm{S} 1=58, \mathrm{~S} 2=145$ and $\mathrm{S} 3=506 \mathrm{mPa} \mathrm{s}$, and $\mathrm{P} 1=48, \mathrm{P} 2=155$ and $\mathrm{P} 3=200 \mathrm{mPa} \mathrm{s}$, respectively.

\section{Viscosity and $p H$ of $1 \%(w / v)$ alginate aqueous solutions}

Three grams of sodium or potassium alginate were dissolved in $300 \mathrm{~mL}$ of distilled water and the viscosity was measured with a Brookfield viscometer model DV-I at $60 \mathrm{rpm}$, at $25^{\circ} \mathrm{C}$ with the $\mathrm{LV}$ spindle No. $2(18.72 \mathrm{~mm}$ diameter, $6.86 \mathrm{~mm}$ high). The viscosity was measured again after adding sodium hexametaphosphate (SHMP) $(0.5 \mathrm{~g}$ per $100 \mathrm{~mL}$ of alginate solution) and stirred for $15 \mathrm{~min}$ to sequestrate the calcium ions present in the solution. The percentage of viscosity reduction was calculated as follows: (viscosity without SHMP-viscosity with SHMP) $\times 100 /$ viscosity without SHMP (Cottrell and Kovacs, 1980); pH was determined with a pHmeter.

\section{Moisture content of the alginate powders}

Seven grams of sodium or potassium alginate were placed in a moisture balance at $110^{\circ} \mathrm{C}$ for $30 \mathrm{~min}$. The moisture content was estimated from the resultant weight loss.

\section{Production of dental impression material using sodium and potassium alginates}

Several $100 \mathrm{~g}$ samples of dental impression material were prepared using S1, S2 and S3 sodium alginates, and P1, P2 and $\mathrm{P} 3$ potassium alginates in 10 different formulations as show in

\section{Material y métodos}

\section{Extracción de alginatos de sodio y de potasio a escala piloto}

Se colocaron $10 \mathrm{~kg}$ de alga seca y molida (M. pyrifera), cosechada en Bahía Tortugas, Baja California Sur, México, en un tanque para su hidratación toda la noche con $90 \mathrm{~L}$ de solución de formalina al $0.1 \%$. La solución residual fue drenada y el alga fue lavada con $100 \mathrm{~L}$ de solución de ácido clorhídrico a pH 4 en el mismo tanque por $15 \mathrm{~min}$, con agitación constante (Hernández-Carmona et al., 1999a). El alga fue transferida a una marmita de extracción, conteniendo $166 \mathrm{~L}$ de agua; el $\mathrm{pH}$ fue ajustado a 10 usando carbonato de sodio en polvo y la solución fue calentada a $80^{\circ} \mathrm{C}$ por $2 \mathrm{~h}$, con agitación constante. La pasta resultante fue diluida a $45 \mathrm{mPa}$ s y filtrada en un filtro rotatorio al vacío, usando tierra de diatomeas como material filtrante (Hernández-Carmona et al., 1999b). Durante la filtración la solución de alginato fue bombeada dentro de un tanque de precipitación, mientras simultáneamente una solución de cloruro de calcio al $10 \%$ fue adicionada para precipitar éste como alginato de calcio, usando una proporción de 2.2 partes de cloruro de calcio por 1 parte de solución de alginato. Las fibras de alginato de calcio fueron blanqueadas usando $700 \mathrm{~mL}$ de una solución de hipoclorito de sodio al 5\%, y convertidas a ácido algínico, con tres lavados ácidos a $\mathrm{pH} 2,1.8$ y 1.8. Las fibras de ácido algínico obtenidas fueron prensadas usando una prensa hidráulica para retirar toda el agua posible (McHugh et al., 2001). Para obtener el alginato de sodio o el alginato de potasio, las fibras de ácido algínico fueron neutralizadas con

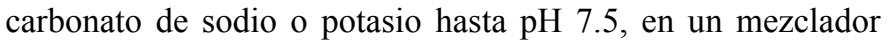
doble planetario durante $40 \mathrm{~min}$. Las fibras de alginato de sodio o potasio fueron separadas y secadas a $60^{\circ} \mathrm{C}$ por el tiempo suficiente para conseguir un producto con $12 \%$ de humedad (Hernández-Carmona et al., en prensa). Se extrajeron tres tipos de alginato de sodio y potasio de tres muetras de algas recolectadas en diferentes fechas, para dar alginatos con viscosidades diferentes que se codificaron, de acuerdo con su viscosidad, como $\mathrm{S} 1=58, \mathrm{~S} 2=145$ y S3 $=506 \mathrm{mPa} \mathrm{s}, \mathrm{y}$ $\mathrm{P} 1=48, \mathrm{P} 2=155$ y P3 $=200 \mathrm{mPa} \mathrm{s}$, respectivamente.

\section{Viscosidad y $\mathrm{pH}$ de las soluciones acuosas de alginato al $1 \%(p / v)$}

Se disolvieron $3 \mathrm{~g}$ de alginato de sodio o potasio en $300 \mathrm{~mL}$ de agua destilada y se midió la viscosidad con un viscosímetro Brookfield modelo DV-I a $60 \mathrm{rpm}$, a $25^{\circ} \mathrm{C}$ con la aguja \#2 LV (18.72 $\mathrm{mm}$ diámetro, $6.86 \mathrm{~mm}$ alto). La viscosidad fue medida nuevamente después de adicionar hexametafosfato de sodio (SHMP) (0.5 g por $100 \mathrm{~mL}$ de solución de alginato) y agitado por 15 min para secuestrar los iones de calcio presente en solución. El porcentaje de reducción de viscosidad fue calculado como sigue: (viscosidad sin SHMP - viscosidad con SHMP) $\times$ 100/viscosidad sin SHMP) (Cottrell y Kovacs, 1980). El pH fue determinado con un potenciómetro. 
table 1. A total of 60 experimental formulations were prepared. Formulation a1 corresponded to the basic formulation proposed by Skinner and Phillips (1982).

\section{Determination of gelling time}

Seven grams of each dental impression formulation (table 1) were mixed with $18 \mathrm{~mL}$ of distilled water for $1 \mathrm{~min}$. The mixture was placed in a dental impression tray and the gelling time was recorded with a chronometer. This time was obtained at the moment when the material stopped being sticky or adherent, and it is of critical importance because it determines the time available to mix the material, fill the impression tray and place it in the patient's mouth by the dentist.

\section{Determination of compressive strength}

Samples of dental impression formulations (table 1) that formed gels using the previous procedure, were placed in a cylindrical geometry ( $3 \mathrm{~cm}$ diameter, $3 \mathrm{~cm}$ high) and placed in a Chatillon Materials Tester, model TCM200, for determining compressive strengths $\left(\mathrm{g} \mathrm{cm}^{-2}\right)$ using a compressive speed of $2.54 \mathrm{~cm} \mathrm{~min}^{-1}$.

\section{Dynamic rheological measurements}

The storage modulus, loss modulus and loss factor (Thomas, 1991) of the dental impression formulations that exhibited higher compressive strength in the previous procedure were determined at a frequency of $1 \mathrm{~Hz}$ over a strain sweep of $1-200 \%$ and a temperature of $25 \pm 0.5^{\circ} \mathrm{C}$ with a high dynamic rheometer Physica DSR 4000. A cone and plate measuring system was used with a cone diameter of $2.5 \mathrm{~cm}$, and a gap between cone and plate of 50 microns. Temperature

Table 1. Formulations used to make the alginate dental impression material.

Tabla 1. Formulaciones usadas para la fabricación de material de impresión dental a base de alginatos.

\begin{tabular}{ccccc}
\hline Formula & $\begin{array}{c}\text { Alginate } \\
(\%)\end{array}$ & $\begin{array}{c}\text { Calcium } \\
\text { sulfate (\%) }\end{array}$ & $\begin{array}{c}\text { Trisodium } \\
\text { phosphate (\%) }\end{array}$ & $\begin{array}{c}\text { Diatomaceous } \\
\text { earth (\%) }\end{array}$ \\
\hline a1 & 12.0 & 12.0 & 2.0 & 74.0 \\
a2 & 10.0 & 12.0 & 2.0 & 76.0 \\
a3 & 15.0 & 12.0 & 2.0 & 71.0 \\
a4 & 20.0 & 12.0 & 2.0 & 66.0 \\
a5 & 25.0 & 12.0 & 2.0 & 61.0 \\
a6 & 12.0 & 10.0 & 2.0 & 76.0 \\
a7 & 12.0 & 15.0 & 2.0 & 71.0 \\
a8 & 12.0 & 20.0 & 2.0 & 66.0 \\
a9 & 12.0 & 12.0 & 1.5 & 74.5 \\
a10 & 12.0 & 12.0 & 1.0 & 75.0 \\
\hline
\end{tabular}

\section{Contenido de humedad de los alginatos en polvo}

Se colocaron $7 \mathrm{~g}$ de alginato de sodio o potasio en una balanza de humedad a $110^{\circ} \mathrm{C}$ por $30 \mathrm{~min}$. El contenido de humedad fue estimado de la pérdida de peso resultante.

\section{Producción de material de impresión dental usando alginato de sodio y potasio}

Se prepararon muestras de $100 \mathrm{~g}$ de material de impresión dental, usando los alginatos de sodio S1, S2 y S3, y los alginatos de potasio P1, P2 y P3 en 10 diferentes formulaciones (tabla 1), para un total de 60 formulaciones experimentales. La formulación a1 correspondió a la formulación básica propuesta por Skinner y Phillips (1982).

\section{Determinación del tiempo de gelificado}

Se mezclaron $7 \mathrm{~g}$ de cada formulación de impresión dental (tabla 1) con $18 \mathrm{~mL}$ de agua destilada por $1 \mathrm{~min}$. La mezcla fue colocada en un molde de impresión dental y el tiempo fue registrado con un cronómetro. Este tiempo se registró en el momento en que el material deja de estar pegajoso o adherente. Esto es de importancia critica debido a que determina el tiempo disponible para mezclar el material, llenar el molde de impresión y colocarlo en la boca del paciente por el dentista.

\section{Determinación de la resistencia a la compresión}

Las muestras de las formulaciones de impresión dental (tabla 1) que formaron geles usando el procedimiento anterior, con una geometría cilíndrica ( $3 \mathrm{~cm}$ diámetro, $3 \mathrm{~cm}$ alto), fueron colocadas en un equipo Chatillon Materials Tester, modelo TCM200, para determinar la resistencia a la compresión $\left(\mathrm{g} \mathrm{cm}^{-2}\right)$ usando una velocidad de compresión de $2.54 \mathrm{~cm} \mathrm{~min}^{-1}$.

\section{Mediciones reológicas dinámicas}

Los módulos de almacenamiento, módulos de pérdida y el factor de pérdida (Thomas, 1991) de las formulaciones de impresión dental que exhibieron mayor fuerza de compresión en el procedimiento 6 , se determinaron a una frecuencia de 1 $\mathrm{Hz}$ sobre un barrido de deformación de $1-200 \%$ y a una temperatura de $25 \pm 0.5^{\circ} \mathrm{C}$ mediante un reómetro dinámico Physica DSR 4000. Se usó un sistema de medición cono y plato con un diámetro de cono de $2.5 \mathrm{~cm}$, y un espacio entre cono y plato de 50 micrones. La temperatura se controló mediante un elemento Peltier. Debido a la sensibilidad del equipo, ninguna de las formulaciones fue medida por debajo del $1 \%$ de barrido de deformación. Para estas mediciones reológicas, se dejó gelificar todas las muestras e inmediatamente se llevaron a cabo las determinaciones.

\section{Resultados}

La tabla 2 muestra los perfiles de calidad de los alginatos de sodio y potasio extraídos de M. pyrifera a nivel piloto, 
control was achieved with a Peltier element. None of the formulations below 1\% strain sweep were measured because the equipment does not have the sensitivity to do it. For these rheological measurements, all samples were allowed to gel and the determinations were immediately carried out.

\section{Results}

Table 2 shows the quality profiles of sodium and potassium alginates extracted from $M$. pyrifera that were used in the elaboration of dental impression formulations. The average viscosities of the $1 \%$ solutions varied between 58 and $506 \mathrm{mPa}$ $\mathrm{s}$ for the sodium alginates and between 48 and200 $\mathrm{mPa}$ s for the potassium alginates. The average viscosity reductions after adding SHMP were never higher than $20 \%$. The $\mathrm{pH}$ of $1 \%$ alginate solutions ranged from 6.4 to 8.2 and moisture content was lower than $14 \%$ in all cases.

Table 3 presents the gelling time of the dental impression materials produced. Dental formulations with S1 and S2 alginates did not form gels; therefore, no data are shown in table 3. Formulations with S3 alginate were type II (regular set), with a gelling time of 121-420 s, except for a1, a8 and a10 that were type I (Fast Set), with a gelling time of 0-120 s. Formulations using the P1 alginate were type II, except for a10 that was type I. Formulations with P2 alginate were type I, except for a6 that was type II. Formulations with P3 alginate were type I, except for a8 and a10 that were type II.

Figure 1 shows the compressive strength of dental impressions produced with the alginates that formed gels. The compressive strength of the gels increased as the percentage of alginate in the formulation was increased to $15 \%, 20 \%$ and $25 \%$ (a3, a4 and a5 formulations) in comparison to the basic formulation (a1) of Skinner and Phillips (1982). The compressive strength within a given formulation varied with the type of

Table 3. Gelling time (seconds) of the dental impression material formulations produced (+1 SD).

Tabla 3. Tiempo de gelificado (segundos) de las diferentes formulaciones de material para impresión denta producidas $( \pm 1 \mathrm{DE})$.

\begin{tabular}{ccccc}
\hline $\begin{array}{c}\text { Formula } \\
\text { used }\end{array}$ & $\begin{array}{c}\text { Alginate } \\
\text { S3 }\end{array}$ & $\begin{array}{c}\text { Alginate } \\
\text { P1 }\end{array}$ & $\begin{array}{c}\text { Alginate } \\
\text { P2 }\end{array}$ & $\begin{array}{c}\text { Alginate } \\
\text { P3 }\end{array}$ \\
\hline a1 & $117 \pm 4$ & $278 \pm 8$ & $67 \pm 8$ & $90 \pm 10$ \\
a2 & $355 \pm 6$ & $375 \pm 15$ & $59 \pm 3$ & $77 \pm 13$ \\
a3 & $305 \pm 4$ & $285 \pm 15$ & $46 \pm 4$ & $120 \pm 10$ \\
a4 & $244 \pm 3$ & $285 \pm 15$ & $90 \pm 10$ & $85 \pm 13$ \\
a5 & $179 \pm 3$ & $262 \pm 19$ & $60 \pm 2$ & $68 \pm 8$ \\
a6 & $384 \pm 4$ & $392 \pm 8$ & $123 \pm 6$ & $92 \pm 10$ \\
a7 & $175 \pm 5$ & $295 \pm 31$ & $75 \pm 15$ & $79 \pm 15$ \\
a8 & $62 \pm 3$ & $135 \pm 15$ & $84 \pm 5$ & $182 \pm 6$ \\
a9 & $205 \pm 5$ & $192 \pm 10$ & $59 \pm 1$ & $74 \pm 4$ \\
a10 & $101 \pm 3$ & $102 \pm 10$ & $51 \pm 3$ & $62 \pm 8$ \\
\hline
\end{tabular}

Table 2. Quality profiles of alginates used in the production of dental impression materials ( $\pm 1 \mathrm{SD})$.

Tabla 2. Perfiles de calidad de los alginatos utilizados en la producción de materiales para impresión dental $( \pm 1 \mathrm{DE})$.

\begin{tabular}{ccccc}
\hline $\begin{array}{c}\text { Alginate } \\
\text { used }\end{array}$ & $\begin{array}{c}\text { Viscosity } \\
(\mathrm{mPa})\end{array}$ & $\begin{array}{c}\text { Reduction of } \\
\text { viscosity }(\%)\end{array}$ & $\mathrm{pH}$ & \multicolumn{1}{c}{$\begin{array}{c}\text { Moisture } \\
(\%)\end{array}$} \\
\hline S1 & $58 \pm 2$ & $13.7 \pm 2.7$ & $6.4 \pm 0.1$ & $9.4 \pm 0.7$ \\
S2 & $146 \pm 3$ & $20.2 \pm 1.3$ & $6.5 \pm 0.1$ & $14.7 \pm 0.2$ \\
S3 & $506 \pm 29$ & $10.5 \pm 3.3$ & $7.8 \pm 0.1$ & $9.0 \pm 0.3$ \\
P1 & $48 \pm 2$ & $15.9 \pm 3.5$ & $7.6 \pm 0.1$ & $12.6 \pm 0.4$ \\
P2 & $155 \pm 3$ & $5.8 \pm 0.9$ & $8.2 \pm 0.1$ & $11.1 \pm 0.5$ \\
P3 & $200 \pm 2$ & $11.0 \pm 0.8$ & $7.7 \pm 0.1$ & $14.0 \pm 0.3$ \\
\hline
\end{tabular}

usados en la elaboración de material de impresión dental. Las viscosidades medias de las soluciones al $1 \%$ variaron entre 58 y $506 \mathrm{mPa}$ s para los alginatos de sodio, y entre 48 y $200 \mathrm{mPa}$ para los de potasio. Las reducciones de viscosidad madia después de agregar HMFS nunca fueron más altas de $20 \%$. El pH de las soluciones de alginato al $1 \%$ osciló entre 6.4 y 8.2 , y el contenido de humedad, en todos los casos, estuvo por abajo del $14 \%$.

La tabla 3 presenta los tiempos de gelificado para los materiales de impresión dental producidos. Las formulaciones dentales hechas con los alginatos S1 y S2 no formaron geles, por lo tanto no se muestra ningún dato en la tabla 3. Las formulaciones con los alginatos S3 fueron de tipo II (fraguado normal), con tiempos de gelificado entre 121 y 420 s, excepto para a1, a8 y a10, que fueron de tipo I (fraguado rápido) y con tiempo de gelificado entre 0 y $120 \mathrm{~s}$. Las formulaciones con alginato P1 fueron de tipo II, excepto para a10 que fue de tipo I. Las formulaciones con alginato P2 fueron de tipo I, excepto para a6 que fue de tipo II. Las formulaciones con alginato P3 fueron de tipo I, excepto para a8 y a10 que fueron de tipo II.

La figura 1 muestra la resistencia a la compresión de las impresiones dentales producidas con los alginatos que formaron geles. La resistencia a la compresión de los geles fue incrementándose cuando el porcentaje de alginato aumentó en las formulaciones a 15\%, 20\% y 25\% (formulaciones a3, a4 y a5) con respecto la formulación básica (a1) de Skinner y Phillips (1982). La resistencia a la compresión en una formulación dada varió con el tipo de alginato usado. Así, para la formulación a5 las resistencias a la compresión fueron, de la más alta a la más baja, de 2474, 2124, 2101 y $1209 \mathrm{~g} \mathrm{~cm}^{-2}$ para los alginatos S3, P1, P2 y P3, respectivamente. También, se dio una ligera tendencia al incremento de la resistencia a la compresión cuando el porcentaje de calcio se incrementó a $15 \%$ y $20 \%$ (formulaciones a7 y a8). A la inversa, las formulaciones a2 y a6 que tuvieron la más baja concentración de alginato y sulfato de calcio mostraron la resistencia más baja a la compresión.

En todas las formulaciones el modulo de almacenamiento $\left(G^{\prime}\right)$ decreció rápidamente con el incremento del porcentaje de 


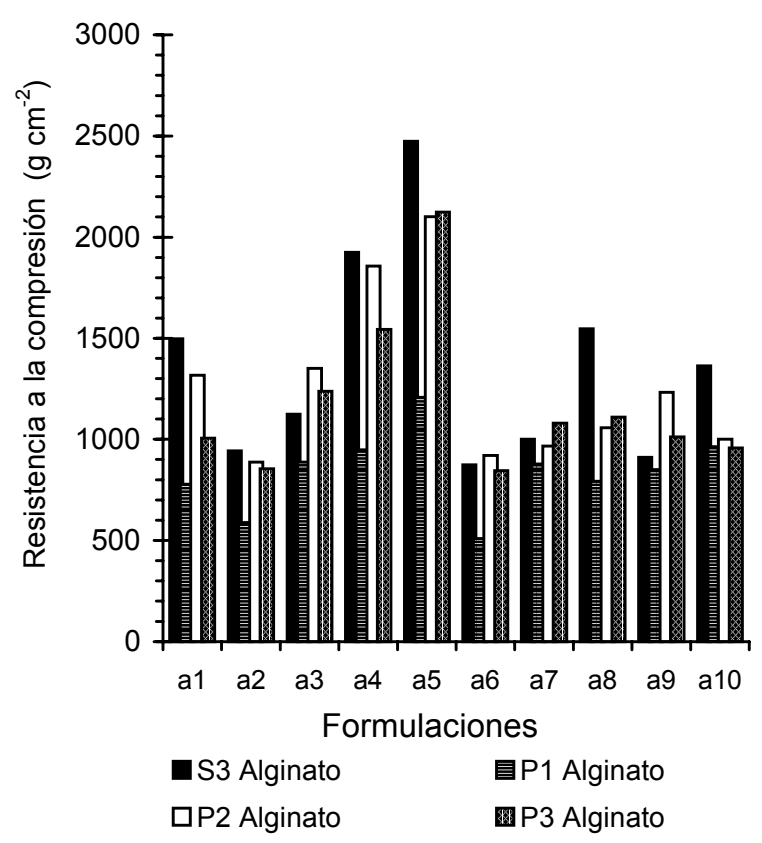

Figure 1. Compressive strength of the dental impression material obtained from alginate gel forming samples.

Figura 1. Resistencia a la compresión del material para impresión dental obtenido con las muestras de alginatos formadores de gel.

alginate used. Thus, in formulation a5 the compressive strengths from higher to lower were 2474, 2124, 2101 and $1209 \mathrm{~g} \mathrm{~cm}^{-2}$ for the S3, P1, P2 and P3 alginates respectively. Also, a slight increasing trend in the compressive strength occurred when the percentage of calcium was increased to 15 and $20 \%$ (a7 and a 8 formulations). Conversely, the a2 and a6 formulations having the lowest alginate and calcium sulfate concentrations showed the lowest compressive strengths.

The storage modulus $\left(G^{\prime}\right)$ decreased sharply with the increase in strain percent $(\gamma)$ in all the formulations, from about $59,500 \mathrm{~Pa}$ at $1 \%$ strain to $7,800 \mathrm{~Pa}$ at $200 \%$ strain (fig. 2). In all cases, the gels did not exhibit linear viscoelastic behavior and as the strain percent increased, a partial breakdown of the elastic structure occurred. The dental impression material prepared with $\mathrm{P} 3, \mathrm{P} 2, \mathrm{P} 1$ and S3 alginates had a higher storage modulus than the commercial control (Jeltrate ${ }^{\circledR}$ ) up to $5 \%$ strain. After this value, a crossover of the $G^{\prime}-\gamma$ curves occurred and Jeltrate ${ }^{\circledR}$ exhibited a slightly higher $\mathrm{G}^{\prime}$. The curves obtained got closer at strains of around $100 \%$. No significant differences were obtained between the experimental formulations.

The loss modulus values (G") decreased with the increase in strain percent. The highest G" value was obtained with P1 alginate, followed by $\mathrm{P} 3, \mathrm{~S} 3$ and $\mathrm{P} 2$ alginates, and Jeltrate ${ }^{\circledR}$ with strains up to $25 \%$, at which a crossover in the G" $-\gamma$ curves occurred (fig. 3).

The loss factor relates the amount of dissipated energy to stored energy. Tan $\delta$ values of all the formulations tended to maintain constant up to strains of about $5 \%$, indicating that the elastic nature of the formulations predominates over their

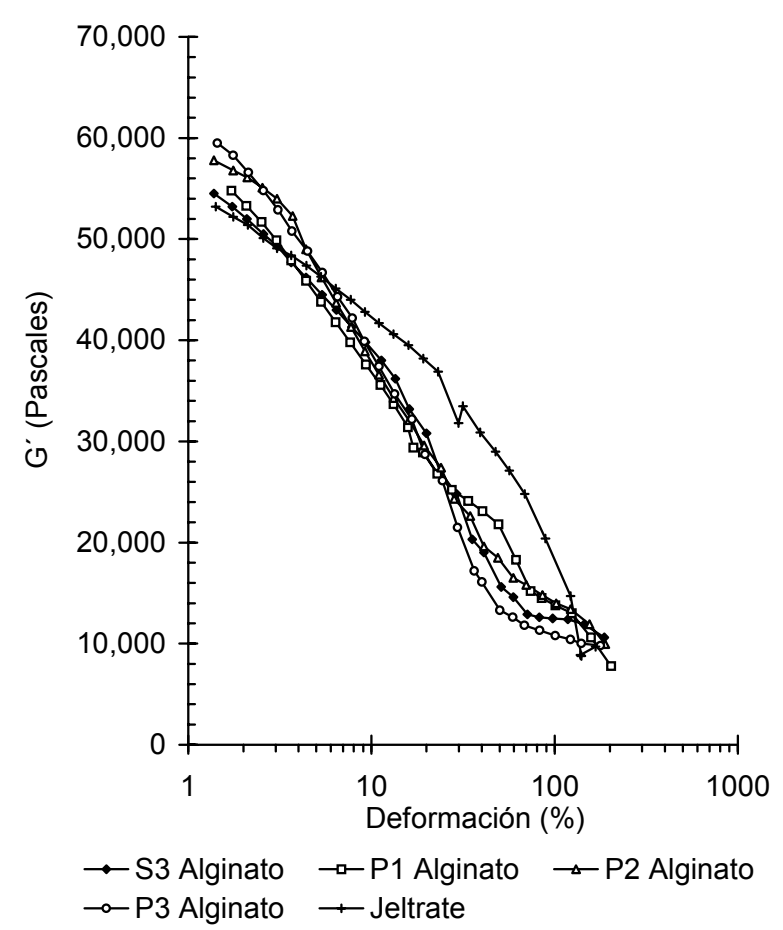

Figure 2. Storage modulus of the alginate dental impression material produced with the a5 formulation.

Figura 2. Módulos de almacenamiento del material para impresión dental producido con alginatos y la formulación a5.

deformación $(\gamma)$ de alrededor de 59,500 Pa a una deformación de $1 \%$, hasta $7,800 \mathrm{~Pa}$ a deformaciones de $200 \%$ (fig. 2). En todos los casos los geles no mostraron comportamiento viscoelástico lineal y al incrementar el porcentaje de deformación ocurrió un rompimiento parcial de la estructura elástica. El material de impresión dental preparado con los alginatos P3, P2, P1 y S3 tuvo un mayor módulo de almacenamiento que el control comercial (Jeltrate ${ }^{\circledR}$ ) hasta una deformación de $5 \%$. Después de este valor ocurre un cruce entre las curvas $G^{\prime}-\gamma$, y Jeltrate ${ }^{\circledR}$ exhibe un G' ligeramente mayor. Las curvas obtenidas se juntaron a deformaciones alrededor de $100 \%$. No se detecto ninguna diferencia significativa entre las formulaciones experimentales.

Los valores de los módulos de pérdida (G”) decrecieron con el incremento del porcentaje de deformación. El valor más alto de G" fue obtenido con el alginato P1, seguido por los alginatos P3, S3, P2 y Jeltrate ${ }^{\circledR}$, con deformaciones hasta de $25 \%$, a la cual ocurre un cruce entre las curvas G"- $\gamma$ (fig. 3).

El factor de pérdida relaciona la cantidad de energía disipada con la energía almacenada. Los valores Tan $\delta$ de todas las formulaciones tienden a mantenerse constantes hasta deformaciones de alrededor de $5 \%$, indicando que la naturaleza elástica de la formulación predomina sobre su naturaleza viscosa (fig. 4). A deformaciones de 5\%, la formulación con el mayor comportamiento elástico fue Jeltrate ${ }^{\circledR}$, seguida en orden decreciente por P2, P3, S3 y P1. Después de 5\%, no se obtuvo ninguna diferencia significativa. 


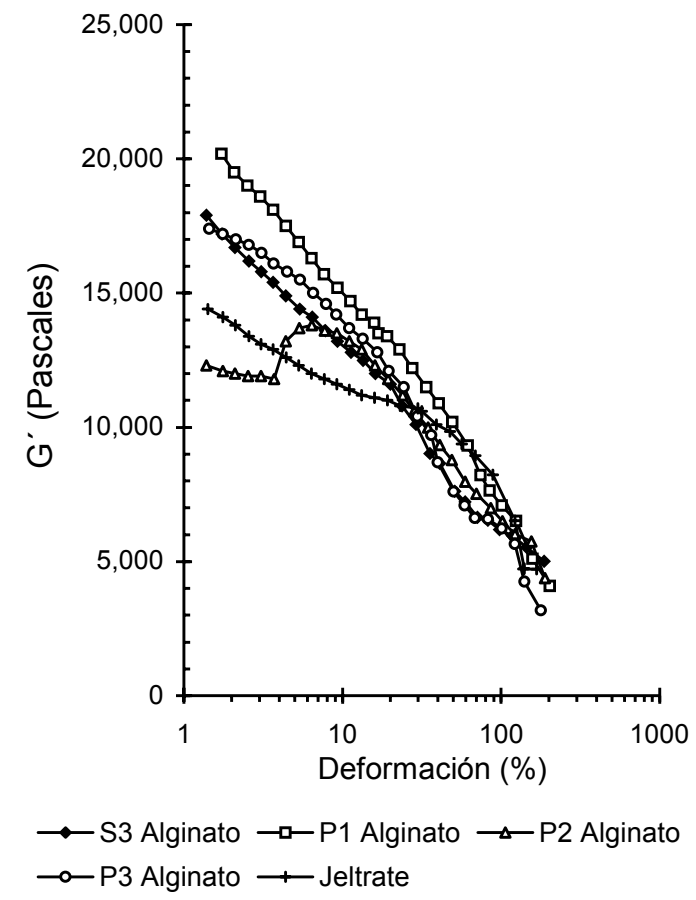

Figure 3. Loss modulus of the alginate dental impression material produced with the a5 formulation.

Figura 3. Módulos de pérdida del material para impresión dental producido con alginatos y la formulación a5.

viscous nature (fig. 4). At 5\% strain the formulation with the highest elastic behavior was Jeltrate ${ }^{\circledR}$, followed in decreasing order by $\mathrm{P} 2, \mathrm{P} 3, \mathrm{~S} 3$ and P1. After 5\%, no significant differences were obtained.

\section{Discussion}

The alginates obtained with the process selected produced a range of products with viscosities from 50 to $506 \mathrm{mPa} \mathrm{s}$ (sodium alginate) and 48 to $200 \mathrm{mPa} \mathrm{s}$ (potassium alginate). One of the quality characteristics of the alginates is their calcium content. This amount is related to the viscosity reduction after one sequestrates the calcium with sodium hexametaphosphate. The maximum reduction allowed by alginate users is $10-40 \%$. This reduction represents about $0.3-1.2 \%$ of the calcium content. In our study, all the samples had less than $20 \%$ calcium; thus, the alginates used in this study fulfilled the commercial quality profiles.

The alginate viscosities are not affected over the $\mathrm{pH}$ range of 5-11. When the alginate is in solution, $\mathrm{pH}$ below 5 causes the $-\mathrm{COO}^{-}$ions in the alginate chain to become protonated to $-\mathrm{COOH}$, so the electrostatic repulsion between chain segments is reduced, being able to come closer and form hydrogen bonds, until a gelatinous precipitate is formed. Above $\mathrm{pH}$ 11, slow depolymerization occurs in stored alginate solutions, causing a decrease in the apparent viscosity (King, 1983). In our case, the $\mathrm{pH}$ of the alginate solutions was between 6.4 and 8.2 and, therefore, a high depolymerization is not likely to occur during the storage period.

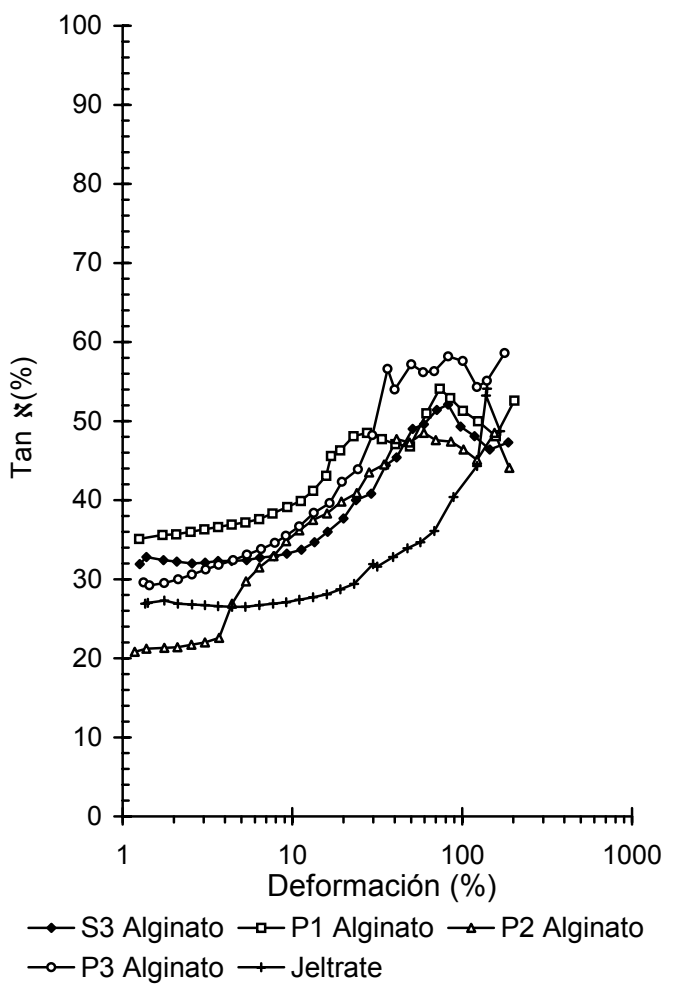

Figure 4. Loss factors of alginate dental impression material produced with the a5 formulation.

Figura 4. Factores de pérdida del material para impresión dental producido con alginatos y la formulación a5.

\section{Discusión}

Los alginatos obtenidos con el proceso seleccionado produjeron productos con un rango de viscosidades entre $50 \mathrm{y}$ $506 \mathrm{mPa}$ s (alginato de sodio) y entre 48 y $200 \mathrm{mPa}$ s (alginato de potasio). Una de las características de calidad de los alginatos es su contenido de calcio. Esta cantidad está relacionada con la reducción de viscosidad una vez secuestrado el calcio con hexametafosfato de sodio. La máxima reducción permisible para los usuarios de alginatos es de 10-40\%. Esta reducción representa alrededor de $0.3-1.2 \%$ de contenido de calcio. En nuestro estudio todas las muestras tuvieron menos de $20 \%$ de reducción de viscosidad y, además, los alginatos utilizados cumplieron con los perfiles de calidad comerciales.

Las viscosidades de los alginatos no son afectadas entre $\mathrm{pH}$ de 5-11. Cuando el alginato está en solución, un pH menor de 5 causa que los iones $-\mathrm{COO}^{-}$en la cadena del alginato se lleguen a protonar a $-\mathrm{COOH}$. Así, la repulsión electroestática se reduce entre los segmentos de la cadena, los cuales al estar más cercanos forman enlaces de hidrógeno hasta que se forma un precipitado gelatinoso. Por arriba de $\mathrm{pH} 11$ ocurre una lenta depolimerización en las soluciones de alginato almacenadas, causando una disminución en su viscosidad aparente (King, 1983). En nuestro caso el $\mathrm{pH}$ de las soluciones de 
Most of the commercial alginates had moisture contents of less than $15 \%$, because the rate of depolymerization of the product increases when the moisture content is higher than $15 \%$ (McHugh, 1987). All the alginates produced in this study had moisture contents of less than $14 \%$.

The dental impression formulations produced experimentally using the P1, P2 and P3 potassium alginates and the S3 sodium alginate formed gels. In contrast, the formulations made with the S1 and S2 alginates did not gel, because of the low polymerization degree (low viscosity) of the sodium alginate. This fact was confirmed since the a5 formulation of the S3 sodium alginate, which had a high viscosity, presented the highest compressive strength value $\left(2474 \mathrm{~g} \mathrm{~cm}^{-2}\right)$. This formulation contained $25 \%$ sodium alginate, $12 \%$ calcium sulfate, $2 \%$ trisodium phosphate, and $61 \%$ diatomaceous earth. This formulation was the closest to the compressive strength specified by the Dental American Association $\left(3500 \mathrm{~g} \mathrm{~cm}^{-2}\right)$ for dental impression alginates (Skinner and Phillips, 1982).

Compressive strength of dental impression materials may depend on the alginate composition (algal species), alginate concentration, its polymerization degree, and calcium concentration. Also, alginates from different seaweeds have differing proportions of manuronic acid and guluronic acid in their structures and different proportions of M, G and MG blocks. For example, the alginates from Laminaria hyperborea have a high percentage of $\mathrm{G}$ blocks, and they can form stronger gels with slight syneresis or water loss. On the contrary, the alginates from M. pyrifera or Ascophyllum nodosum have a high proportion of M blocks, and form softer and more elastic gels, but with higher syneresis (Smidsrod and Draget, 1996). In our case, the most important factor to increase the compressive strength of the dental impression material formulated was the polymerization degree; however, it could be improved if the alginate viscosity is increased to values of $600-700 \mathrm{mPa}$ s. The alginate viscosity can be increased if the extraction is carried out from fresh harvested kelp, as is generally done by alginate factories (personal observation). The commercial sodium alginate viscosity produced by ISP in USA from $M$. pyrifera can be as high as $1300 \mathrm{mPa}$ s (1\% solution).

The storage modulus represents the elastic behavior of the gel in the dental impression material prepared. The G' decreased when the strain was increased in all the experimental formulations and controls. Although the gels did not show a linear viscoelastic behavior, the relation was similar for all cases and the breakdown of the elastic structure occurred at about the same strain percent.

The loss modulus (G") represents the viscous behavior of the formulation. As expected, G" also decreased when the strain was increased and after $25 \%$ all curves were similar, indicating properties similar to the control. The loss factor relates the amount of dissipated energy to stored energy. Tan $\delta$ values of all the formulations tended to maintain constant up to strains of about $5 \%$, indicating that the elastic nature of the formulations predominates over their viscous nature. However, at larger strains value, Tan $\delta$ increased for all formulations, alginato estuvo entre 6.4 y 8.2 y, por lo tanto, no ocurrió una depolimerización durante el periodo de almacenamiento.

La mayoría de los alginatos comerciales tienen contenidos de humedad menores a $15 \%$ debido a que la tasa de depolimerización del producto se incrementa cuando el contenido de humedad es mayor a 15\% (McHugh, 1987). Todos los alginatos producidos en este estudio tuvieron contenidos de humedad menores a $14 \%$.

Las formulaciones de impresiones dentales producidas experimentalmente usando los alginatos de potasio P1, P2 y $\mathrm{P} 3$, y el alginato de sodio S3, formaron geles. Por lo contrario, las formulaciones elaboradas con los alginatos $\mathrm{S} 1$ y S2 no formaron geles, debido al bajo grado de polimerización (baja viscosidad) del alginato de sodio. Este hecho fue confirmado ya que la formulación a5 del alginato de sodio S3, de alta viscosidad, presentó el más alto valor de resistencia a la compresión (2474 $\left.\mathrm{g} \mathrm{cm}^{-2}\right)$. Esta formulación contenía $25 \%$ de alginato de sodio, $12 \%$ de sulfato de calcio, $2 \%$ de fosfato trisódico y $61 \%$ de tierra de diatomeas y fue la que alcanzó la resistencia de compresión más cercana a la especificada por la Asociación Dental Americana $\left(3500 \mathrm{~g} \mathrm{~cm}^{-2}\right)$ para alginatos de impresión dental (Skinner y Phillips, 1982).

La resistencia a la compresión de los materiales de impresión dental puede depender de la composición del alginato (especie de alga), concentración de alginato, su grado de polimerización y la concentración de calcio. También, los alginatos de diferentes algas marinas tienen diferentes proporciones de ácidos manurónicos y gulurónicos en sus estructuras y diferentes proporciones de bloques M, G y MG. Por ejemplo, los alginatos de Laminaria hyperborea tienen un porcentaje alto de bloques $\mathrm{G}$ y pueden formar geles más fuertes con poca sinéresis o pérdida de agua. Por el contrario, los alginatos de $M$. pyrifera o Ascophyllum nodosum tienen una alta proporción de bloques $\mathrm{M}$, y forman geles más suaves y elásticos, pero con alta sinéresis (Smidsrod y Draget, 1996). En nuestro caso, el factor más importante para incrementar la resistencia a la compresión del material de impresión dental formulado fue el grado de polimerización; sin embargo, éste pudiera ser mejorado si la viscosidad del alginato se incrementa a valores en el orden de 600 a $700 \mathrm{mPa}$ s. La viscosidad del alginato puede ser incrementada si la extracción es realizada con algas recién cosechadas, como generalmente es hecho en las fabricas de alginatos (observación personal). La viscosidad del alginato de sodio comercial producido por ISP en EUA a partir de $M$. pyrifera puede ser tan alta como $1300 \mathrm{mPa}$ s (solución al 1\%).

Los módulos de almacenamiento representan el comportamiento elástico del gel en el material de impresión dental preparado. La G' disminuyó cuando se incrementó la deformación en todas las formulaciones experimentales y el control. Aunque los geles no mostraron un comportamiento viscoelástico lineal, la relación fue similar en todos los casos y el rompimiento de la estructura elástica ocurrió al mismo porcentaje de deformación. 
suggesting that as the partial breakdown of the elastic structure proceeds with increasing strain, a change to a relatively more viscous behavior of the formulations takes place. This viscous nature reaches a peak for most formulations at a strain of about $80 \%$. Although the formulation that presented the largest elastic behavior was Jeltrate ${ }^{\circledR}$, the values obtained for P2 were similar to the Jeltrate control.

The rheological characterization of the dental impression alginates indicates that the elastic behavior of all the a5 formulations was slightly lower than the commercial product (Jeltrate ${ }^{\circledR}$ ); however, this could be improved by using higher molecular weight potassium or sodium alginates, with viscosities higher than $500 \mathrm{mPa}$ s. Also, it could be improved by combining the use of modifiers such as magnesium oxide, potassium sulfate, sodium silicoflouride and other types of diatomaceous earths. The effect of these proposed modifications will be discussed in another paper. A further study using alginates extracted from Sargassum algae is also recommended, as they have a high percentage of guluronic acid and may form stronger gels (Shyamali et al., 1984; Wedlock et al., 1986). The total biomass of Sargassum in the Gulf of California, Mexico, has been estimated to be 31,000 \pm 3,200 dry tons (Pacheco-Ruíz et al., 1998).

We concluded that the P1, P2 and P3 potassium alginates, as well as the $\mathrm{S} 3$ sodium alginate extracted from M. pyrifera algae at the pilot plant scale, have a good potential to be used in the production of dental impression materials.

\section{Acknowledgements}

We acknowledge the United Nations Development Program (FAO) for the financial support to construct the pilot plant for alginate production. Thanks to Rubén Ortega (Paar Physica Company) for technical assistance in determining the rheological properties of the samples.

\section{Referencias}

Cottrell, I.W. and Kovacs, P. (1980). Alginates. In: R.L. Davidson (ed.), Handbook of Water-soluble Gums and Resins. McGrawHill, pp. 2.1-2.42.

Hernández-Carmona, G., Rodríguez-Montesinos, Y.E., TorresVillegas, J.R., Sánchez-Rodríguez, I. y Vilchis MA (1989a). Evaluación de los mantos de Macrocystis pyrifera (PhaeophytaLaminariales) en Baja California, México. I. Invierno 1985-1986. Cienc. Mar., 15(2): 1-27.

Hernández-Carmona, G., Rodríguez-Montesinos, Y.E., TorresVillegas, J.R., Sánchez-Rodríguez, I., Vilchis, M.A. y García-de la Rosa, O. (1989b). Evaluación de los mantos de Macrocystis pyrifera (Phaeophyta, Laminariales) en Baja California, México. II. Primavera 1986. Cienc. Mar., 15(4): 117-140.

Hernández-Carmona, G., Rodríguez-Montesinos, Y.E., Casas-Valdez, M.M., Vilchis, M.A. y Sánchez-Rodríguez, I. (1991). Evaluación de los mantos de Macrocystis pyrifera (Phaeophyta, Laminariales) en la península de Baja California, México. III. Verano 1986 y variación estacional. Cienc. Mar., 17(4): 121-145.

Hernández-Carmona, G., McHugh, D.J., Arvizu-Higuera, D.L. and Rodríguez-Montesinos, Y.E. (1999a). Pilot plant scale extraction
Los módulos de pérdida (G”) representan el comportamiento viscoso de las formulaciones. Como se esperaba, G" también decreció cuando se incrementó la deformación y, después de $25 \%$, todas las curvas fueron similares, indicando propiedades similares al control. El factor de pérdida relaciona la cantidad de energía disipada con la almacenada. Los valores de $\operatorname{Tan} \delta$ de todas las formulaciones tendieron a mantenerse constantes hasta deformaciones de alrededor de $5 \%$, indicando que la naturaleza elástica de las formulaciones predomina sobre su naturaleza viscosa. Sin embargo, a mayores valores de deformación, Tan $\delta$ se incrementó para todas las formulaciones, sugiriendo un rompimiento parcial de la estructura elástica $\mathrm{y}$, al proceder el incremento de la deformación el comportamiento de las formulaciones cambia uno relativamente más viscoso. Esta naturaleza viscosa, para la mayoría de las formulaciones, alcanza un máximo a deformaciones de alrededor del $80 \%$. Aunque la formulación que presentó el mayor comportamiento elástico fue Jeltrate ${ }^{\circledR}$, los valores obtenidos para P2 fueron similares al control Jeltrate.

La caracterización reológica de los alginatos de impresión dental indica que, del comportamiento elástico de todas las formulaciones, a5 fue ligeramente menor que el producto comercial (Jeltrate ${ }^{\circledR}$ ); sin embargo, esto pudiera ser mejorado por el uso de alginatos de sodio o potasio de mayor peso molecular, con viscosidades mayores que $500 \mathrm{mPa}$ s. También, esto pudiera ser mejorado con la combinación del uso de modificadores tales como óxido de magnesio, sulfato de potasio, silicofluoruro de sodio y otros tipos de tierras de diatomeas. El efecto de estas modificaciones propuestas será discutido en otro artículo. También se recomienda realizar un estudio utilizando alginatos extraídos del alga Sargassum, los cuales tienen un porcentaje alto de ácido gulurónico y pudieran formar geles más fuertes, de acuerdo con Shyamali et al. 1984 y Wedlock et al., 1986. La biomasa total de Sargassum en el Golfo de California fue estimada en 31,000 $\pm 3,200 \mathrm{t}$ secas (PachecoRuíz et al., 1998).

Se concluye que tanto los alginatos de potasio P1, P2 y P3 como el alginato de sodio S3, extraídos del alga M. pyrifera a escala planta piloto, tienen un buen potencial para ser usados en la producción de materiales de impresión dental.

\section{Agradecimientos}

Se agradece al Programa de Naciones Unidas para el Desarrollo (FAO) el soporte financiero para la construcción de la planta piloto de producción de alginatos. Gracias a Rubén Ortega (Compañía Paar Physica) por la ayuda técnica para la determinación de las propiedades reológicas de todas las muestras.

Traducido al español por los autores. 
of alginate from Macrocystis pyrifera. I. The effect of preextraction treatments on the yield and quality of alginate. J. Appl. Phycol., 10: 507-513.

Hernández-Carmona, G., McHugh, D.J. and López-Gutiérrez, F. (1999b). Pilot plant scale extraction of alginate from Macrocystis pyrifera. 2. Studies on extraction conditions and methods of separating the alkaline-insoluble residue. J. Appl. Phycol., 11: 493-502.

Hernández-Carmona, G., McHugh, D.J., Arvizu-Higuera, D.L. and Rodríguez-Montesinos, Y.E. (2002). Pilot plant scale extraction of alginates from Macrocystis pyrifera. 4. Conversion of alginic acid to sodium alginate, drying and milling. J. Appl. Phycol (in press).

King, A.H. (1983). Brown seaweed extracts (alginates). In: Food Hydrocolloids. CRC Press, pp. 115-188.

McHugh, D.J. (1987). Production, properties, and uses of alginates. In: D.J. McHugh (ed.), Production and Utilization of Products from Commercial Seaweeds. FAO Fish. Tech. Pap., 288: 58-115.

McHugh, D.J., Hernández-Carmona, G., Arvizu-Higuera, D.L. and Rodríguez-Montesinos, Y.E. (2001). Pilot plant scale extraction of alginate from Macrocystis pyrifera. 3. Precipitation, bleaching and conversion of calcium alginate to algnic acid. J. Appl. Phycol., 13: 471-479.

Osborne, J., Wilson, H.J. y Mansfield, M.A. (1987). Tecnologías y Materiales Dentales. Editorial Limusa, México, 520 pp.

Onsoyen, E. (1996). Commercial applications of alginates. Carbohydrates in Europe, 14: 30-31.

Pacheco-Ruíz, I., Zertuche-González, J.A., Chee-Barragán, A. and Blanco-Betancourt, R. (1998). Distribution and quantification of Sargassum beds along the west coast of the Gulf of California,
Mexico. Walter de Gruyter, Berlin, 41: 203-208.

Reyes-Tisnado, R., Hernández-Carmona, G. y Hernández-Valenzuela, R. (1992). Reducción del consumo de agua dulce en el proceso de extracción de alginatos a partir de Macrocystis pyrifera (Phaeophyta, Laminariales), mediante recirculaciones de los líquidos residuales de la pre-extracción y precipitación. Cienc. Mar., 18(3): 105-124.

Reyes-Tisnado, R., López-Gutiérrez, F., Hernández-Carmona, G. y Castro-Moroyoqui, P. (2000). Propiedades Fisicoquímicas de los Alginatos, Polisacáridos de las Algas Phaeophytas. SEMARNAPINP-CRIP, La Paz, México, 72 pp.

Shyamali, S., de Silva, M. and Savitri Kumar, N. (1984). Composition and sequence of uronate residues in alginates from some brown seaweeds. J. Nat. Sci. Counc. Sri Lanka, 12: 161-166.

Skinner, EW. y Phillips, R.W. (1982). La ciencia de los materiales dentales. Editorial Mundi, México, pp. 124-142.

Skjäk-Braek, G. and Martinsen, A. (1991). Application of some algal polysaccharides in biotechnology. In: Seaweed Resources in Europe: Uses and Potential. John Wiley, pp. 219-258.

Smidsrod, O. and Draget, K.I. (1996). Chemistry and physical properties of alginate. In: Carbohydrates in Europe, 14: 6-11.

Thomas, M. (1991). Oscillation Test. In: Course in Rheology. Paar Physica Co., Germany, pp. 4-21.

Wedlock, D.J., Fasihuddin, B.A. and Phillips, G.O. (1986). Characterization of alginates from Malaysia. In: G.O. Phillips, D.J. Wedlock and P.A. Williams (eds.), Gums and Stabilizers for the Food Industry. Elsevier, London, pp. 47-67. 